\title{
US-China Rivalry in the twenty-first century: Déjà vu and Cold War II
}

\section{Avery Goldstein ${ }^{1}$}

Received: 21 March 2020 / Accepted: 20 May 2020 / Published online: 2 June 2020

(C) The Institute of International and Strategic Studies (IISS), Peking University 2020

\begin{abstract}
In 2019, US-China relations that had been characterized by a pattern of ups and downs over the past quarter century took a clear and possibly irreversible turn for the worse. This change has provoked debate about whether China and the US have already become rivals, perhaps adversaries, in a new cold war. I examine five underlying influences shaping the newly intensifying rivalry. These influences reflect key features of the international context within which the US and China find themselves (systemic or structural constraints) and the fact that the two rivals happen to be the US and China (national or unit-level attributes). Chief among the international constraints are the structural conditions of anarchy and the distribution of power that defines the system's polarity. The national attributes most relevant to understanding the evolution of US-China relations are the geography of the theater where the two countries' vital interests intersect and two aspects of their militarily relevant technological capabilities. Examining these five influences draws attention to reasons for some important similarities but also differences between the current rivalry and the Soviet-American rivalry of the Cold War. It makes clear that a Cold War II, if that is what is emerging, will not simply replicate the rivalry of Cold War I. Unfortunately, this examination also directs attention to some troubling new concerns about the distinctiveness of the new rivalry and the challenges they may present in the coming decades.
\end{abstract}

Keywords Cold war $\cdot$ China $\cdot$ United States $\cdot$ Bipolarity $\cdot$ Nuclear deterrence Anarchy $\cdot$ Cyberattacks

Avery Goldstein

agoldstn@sas.upenn.edu

1 Political Science Department, University of Pennsylvania, Philadelphia, PA, USA 


\section{Introduction}

In 2019, US-China relations that had been characterized by a pattern of ups and downs over the past quarter century took a clear and possibly irreversible turn for the worse. A relationship that had been characterized by a mix of cooperation and limited competition during the 1990s and first decade of the twenty-first century was tested by rising tensions during the Obama administration that set the stage for an apparently decisive change during the presidency of Donald Trump. Remarkably quickly, an emerging debate in the US about what was loosely labeled engagement morphed into a debate about whether China and the US had already become rivals, perhaps adversaries, in a new cold war. At academic conferences and track-two dialogues, and in the pages of journals and newspapers, US observers were quick to see similarities between the 4-decade long era of Soviet-American confrontation and the newly fraught Sino-American relationship. ${ }^{1}$ Chinese colleagues were more reluctant to accept the usefulness of the Cold War comparison, but over time some began to echo their American counterparts and debate its merits. Although everyone recognizes that the world in 2020 is different than the world during the Cold War era, and that the disagreements between China and the US are different than those that drove Soviet-American rivalry, the Cold War analogy has demonstrated a stubborn appeal. ${ }^{2}$

To shed additional light on the usefulness and limits of the Cold War comparisons, this article looks at key influences shaping the newly rivalrous Sino-American relationship. In so doing, it also indicates that the ostensibly quick shift from limited competition in the context of engagement to the more openly confrontational rivalry that some dub a new cold war in part reflects causes that were already in play by the late 1990s. This transition away from engagement most likely would have begun sooner, and would have proceeded more gradually after 2001, were it not for the US response to the September 11, 2001 attacks on America. These attacks diverted the newly elected George W. Bush administration from its original plan to focus on redefining US-China relations as a strategic competition rather than a partnership. Instead, it began to focus on the demands of its "Global War on Terrorism". Thus, it was not until later in the decade, as the US wound down its major military operations across Afghanistan, Iraq, and other areas of the Middle East and Africa, that the American concerns about China's rise that had prompted the Bush administration's thinking before September 2001 resurfaced. When they did, they were magnified by the dramatic transformations in China's wealth and power that had taken place during the first decade of the new century. These concerns informed the Obama administration's decision to rebalance the priorities of American strategy and focus on the challenges and opportunities which it saw in the Asia Pacific (Clinton 2011). The declared rebalance_colloquially known as "the pivot"-set the

\footnotetext{
${ }^{1}$ For a sampling of the range of views, see Lind (2018), Allison (2018), Kaplan (2019), The Economist (2019), Marston (2019), Edel and Brands (2019), Mead (2019), Ferguson (2019) and Leffler (2019).

2 The analogy can be useful, if carefully invoked, as Yuen Foong Khong (2019) has explained. On the usefulness and limits of historical analogies, see also May (1973) and Khong (1992).
} 
stage for increased competition between the United States and China in the region. It is the intensification of that competition during the Trump administration that has prompted many to think about the possibility that the US and China are in the early stages of a "new Cold War" or "Cold War II".

In what follows, I examine five underlying influences shaping the newly intensifying Sino-American rivalry. These influences reflect key features of the international context within which the US and China find themselves (systemic or structural constraints) and the fact that the two rivals happen to be the US and China (national or unit-level attributes). Chief among the international constraints is the structural condition of anarchy and the distribution of power that defines the system's polarity. The national attributes most relevant to understanding the evolution of US-China relations are the geography of the theater where the two countries' vital interests intersect and two aspects of their militarily relevant technological capabilities. Examining these five influences draws attention to reasons for some important similarities but also differences between the current rivalry and the Soviet-American rivalry during the Cold War. It makes clear that a Cold War II, if that is what is emerging, will not simply replicate the rivalry of Cold War I. Unfortunately, it also directs attention to some troubling new concerns about the distinctiveness of the US-China rivalry and the challenges which they may present in the coming decades.

\section{Anarchy: old cause, new implications}

The condition of anarchy, the absence of a supranational authority that can reliably resolve disputes among states, constrains all to think about the possibility that they will need to provide for their own security. When the intensity of such security concerns deepens, states are more likely to worry about their vulnerabilities. These vulnerabilities are not limited to the military threats that others could pose; they include the vulnerabilities that result from economic interdependence. Although these consequences of anarchy are not new, compared with the US-Soviet experience, the implications for US-China relations, especially economic relations, are different. ${ }^{3}$

From the beginning of the Cold War, security concerns about the mutual vulnerabilities inherent in economic interdependence led both the Soviets and the US to preclude broad and deep economic exchanges with each other. Each instead established its own economic bloc that basically conformed with its security alliance networks. By contrast, during the last decades of the Cold War, when the US and China were strategic partners opposing the Soviet Union, and then especially after 1978, when leaders in Beijing embraced policies of "reform and opening up", China and

\footnotetext{
${ }^{3}$ I focus on the potential security threats that result from the condition of anarchy. Others, skeptical about the centrality of this traditional survival concern for the US or China, have looked at competition for international prestige, status, or authority (Lake 2017). Without denying that these other, ideational, considerations matter (evident in the competing narratives from the US and China that seek to shape international perceptions of their responses to the COVID-19 pandemic), concerns about relative material capabilities remain central because they underpin coercive power that - at least in the short termtrumps prestige, status, and authority as a means to address pressing threats to vital interests.
} 
the US grew increasingly interdependent. As long as US-China relations were characterized by limited competition during the heyday of engagement, each was comfortable with a focus on the mutual benefits they derived from economic exchanges. In a phrase often invoked by the Chinese side, these exchanges resulted in "win-win outcomes". To the extent there were concerns about security implications that might arise in an anarchic realm, they seemed like remote possibilities, or at least problems to be addressed at a later date, if necessary. In the near term, there was a willingness to try to manage such concerns through bilateral talks or by relying on multilateral economic institutions, especially the World Trade Organization. However, as rivalry took root, attention shifted from "win-win" to "who wins more?" Or as the literature about the consequences of anarchy often notes, each side began to focus on relative gains rather than the absolute gains each side derived from their thick economic ties. ${ }^{4}$ Although these kinds of concerns reflect the enduring international condition of anarchy in which states coexist, their significance varies depending on whether states see each other as rivals whose uncertain intentions and capabilities could be threatening. In the case of China and the US, it was the shift to perceiving one another as rivals that elevated concerns about vulnerability. As that happened, bilateral negotiations became more difficult and the limits to the effectiveness of international regimes became more salient.

As rivalry deepened, the US worried that a relaxed policy of engagement was helping to make China richer and stronger, nurturing a rising great power that could ultimately jeopardize American security. This concern had first emerged at the turn of the century, when it motivated the United States Congress to establish the US-China Economic and Security Review Commission in 2000. But prior to the shift to serious rivalry, the role played by this body and other government tools to manage security concerns about economic relations, such as the Committee on Foreign Investment in the United States (CFIUS), was not as consequential as the Cold War's Coordinating Committee for Multilateral Export Controls (CoCom), which had sharply restricted Western economic ties with members of the Soviet bloc's Council for Mutual Economic Assistance (Comecon); in part, because US security concerns were focused on Afghanistan and Iraq after the September 11 attacks, and because most American consumers were enjoying significant benefits from economic ties with a booming China, the US gave short shrift to the vulnerabilities that accompanied deepening interdependence.

In the 2010s, however, as the US refocused on an Asia-Pacific region where China was not only an economic behemoth but an increasingly capable and active military power, American anxiety about the risks of interdependence deepened. Washington became ever more serious about regulating trade and investment with China and began to act on security concerns that looked much more worrisome from the American perspective than they had seemed at the start of the century. ${ }^{5}$ However, because of China's outsized economic role in global supply chains with

\footnotetext{
${ }^{4}$ On the implications of conflicts that can result from economic interdependence, see Waltz (1979), chapter 7 .

5 On the recent "securitization" of US-China relations, see Medeiros (2019).
} 
which the US and others were thoroughly integrated, acting on these new concerns would be difficult and costly. In contrast with the Cold War, when US policies since the late 1940s had aimed to avert a coupling of the American and Soviet economic orders, in the 2010s reducing US-China economic interdependence would entail what quickly became known as decoupling. This decoupling, unwinding the existing ties, promises to be a novel, highly disruptive process that will require major adjustments by both countries and their economic partners around the world-a prospect for which the Cold War experience provides little insight. Moreover, it seems likely that decoupling will itself reinforce the security concerns resulting from anarchy as each side becomes painfully aware of the array of vulnerabilities, their interdependence has created.

Some changes reflecting these newly salient concerns are already evident in the broadening sectors in which the US is reconsidering the legacy of close engagement with China. Washington's fears about China's companies playing a role in upgrading American infrastructure-from telecoms in the new 5G era to railcars and buses in mass transit for American cities-reflect the growing unease about links between economic interdependence and national security. The tightening of US visa policies and regulations governing the access of China's students and scholars to educational institutions and research labs in the US is another manifestation of the way rivalry has altered the calculation of costs and benefits. Exchanges previously deemed mutually beneficial are now seen as problematic, because the US worries they might result in China acquiring expertise that could enhance its economic or military power relative to the US.

American measures have in turn nurtured similar concerns in China about the implications of its own vulnerability, which resulted from decades of deepening economic interdependence. Particularly worrisome is China's dependence on American sources for crucial inputs to technologically advanced sectors at the heart of Beijing's vision for the next stage of China's economic modernization. The response to this worry was already manifest in the Made in China 2025 (MIC 2025) initiative, which aimed to reduce China's heavy dependence on the US for critical components. Although the visibility of MIC 2025 diminished as government subsidies became a point of contention in US-China trade negotiations, Beijing's motivation to seek greater self-reliance remained. Indeed, its urgency was underscored as the US instituted rules that restricted, and in some cases banned, the operations of China's telecoms in the American market and pressed a global campaign to convince allies, partners, and others to follow suit. Thus, even though President Trump granted one company (ZTE) a reprieve from what at first looked like a ban that would put it out of business, subsequent American restrictions on Huawei threatened to undermine the global viability of China's leading international technology company. Beijing predictably responded by increasing its investment in indigenous research and development as part of a push for greater self-reliance. The aim was not only to ensure the continued viability of particular companies like Huawei, but more broadly to reduce the leverage that the US derives from its role as a source of key technologies that have commercial and military applications.

Concerns about interdependence, which have been shaping new rules governing market access for Chinese and American investors and for protecting essential 
technologies in sensitive sectors, have loomed over the bilateral negotiations to resolve the tariff-driven trade war that began in 2018. The phase one agreement concluded in early 2020 suggested success in easing tensions. However, the more difficult issues were not addressed in phase one. These include security concerns about the implications of interdependence, which were pushed off to future talks. The structural constraint of international anarchy, however, will make it difficult for negotiations to resolve these issues. Even if progress is made and a phase two deal can be reached, its significance would remain uncertain. In the anarchic international realm, formal agreements, while often helpful to the extent they reduce uncertainty, guide behavior, and shape expectations, are ultimately self-enforcing contracts. Even the most carefully crafted agreement cannot eliminate doubts about future behavior. And because the US and China now view one another as rivals, the implications of such doubts for their security concerns are hard to dispel.

As a consequence of anarchy, the decoupling that has begun is likely to continue in some form. The question is instead of how far it will proceed and with what effects. Decoupling, even if partial, will introduce inefficiencies as economic decisions are shaped by political regulations that were less significant in the heyday of engagement. The opportunity costs of decoupling will include forgoing supply chains that make economic sense and forgoing some areas of international collaboration in research and development that contribute to scientific progress. The severe disruptions and dislocations experienced during the COVID-19 pandemic starkly illustrate the possible implications of US-China rivalry in the shadow of anarchy for a globalized order. Nevertheless, in another example of what John Mearsheimer famously referred to as the tragedy of great power politics, both China and the United States may well decide that their vital security interests justify incurring steep opportunity costs (Mearsheimer 2001; see also Farrell and Newman 2019).

\section{From unipolarity to bipolarity: old cause, old implications}

The evolution of US-China relations during the past 2 decades has unfolded not only in the shadow of anarchy, but at a time when the distribution of power in the international system was shifting. China's rise, which accelerated after the mid1990s, initiated a transition away from the post-Cold War condition of unipolarity marked by America's position as a peerless superpower. That transition pointed towards a bipolar world emerging sometime in the first half of the twenty-first century, a world in which China and the United States would comprise a distinctive pair whose great power capabilities set them apart from all others on the global stage. To be clear, bipolarity is not defined by the equivalence of the two leading states in the international system, but by the large gap between their capabilities and those of the next most powerful group of states. Nor does bipolarity (or multipolarity for that matter) indicate symmetry in the composition of the capabilities of the great powers. During the Cold War, for example, the Soviet Union failed to match the capabilities of the United States, especially in terms of economic strength and the quality of advanced military weaponry. Nevertheless, its massive conventional forces and nuclear arsenal, along with a large, if lagging, economy and a tightly disciplined 
political leadership, provided the Soviet Union with aggregate capabilities that enabled it to compete with and pose a threat to the interests of the United States in ways that no other state could match. ${ }^{6}$

As early as the end of the twentieth century, China had already emerged as the only plausible candidate to end the post-Cold War unipolar era of American primacy. Before the United States turned its attention to the global war on terror in the fall of 2001, the dawning realization that it had to anticipate the arrival of this new superpower motivated the Bush administration's initial plans to deal with China as a competitor. By the time the US redirected its strategic focus to East Asia under President Obama, the significance of China's economic and military rise had become unmistakable. If unipolarity had not yet ended, the handwriting was on the wall. ${ }^{7}$

Theorists who had explored the consequences of great power competition during the Cold War, most notably Kenneth Waltz (1979), indicated that the "duopolists" in a bipolar system have strong incentives to monitor one another closely and compete widely lest the other gain a strategic advantage. And in a bipolar world, each knows that only it has the massive array of capabilities to respond effectively to the threat which the other might represent. With the impending advent of bipolarity in the twenty-first century, China and the US have begun to respond to its constraints in ways that echo the behavior of the Soviet Union and the United States in the last century. During the second decade of the twenty-first century, US-China competition has become ever keener and has begun to spread well beyond the confines of East Asia. Washington has expressed concern about China's growing international economic role and its expanding (if still limited) military presence from Africa to the Arctic. Beijing, in turn, has criticized US rhetoric and actions that target China's greater influence, arguing that American alarmism unjustifiably impugns China's benign interest in playing a constructive role in global governance and assuming international responsibilities consistent with its increasing capabilities. This

\footnotetext{
${ }^{6}$ On the meaning of bipolarity, including the distinction between it and a division of the world into two ideologically polarized camps, see Waltz (1979) and Tunsjo (2018). On the question of asymmetry in bipolar worlds, see Yan (2015, 2019a).

7 See also Tunsjø (2018) and Yan (2015). Calculations about economic and military capabilities are inevitably contested. But on both dimensions the US and China stood apart at the end of the 2010s. Using the relatively conservative estimates of nominal GDP calculated at currency exchange rates (rather than purchasing power parity, which boosts the estimates of some countries) from the IMF's World Economic Outlook Database, the United States remained the world's largest economy. China's was roughly two-thirds that of the US. Although that meant that the American economy was still 50\% larger, that difference pales in comparison with the gap between China and the rest. China's economy was three times larger than the two in the next tier (Japan and Germany), and five times larger than the tier after that (the UK, France, and India). Estimates of military capabilities are especially difficult because of secrecy in the data and because analysts recognize that military spending and the quantity of weapons systems and personnel may fail to capture true military power, which also depends on the quality of forces, training, and experience. Nevertheless, estimates of military spending from the Stockholm International Peace Research Institute are suggestive. The US remains in the lead, with military spending 2.5 times greater than China's, while China spends nearly four times that of the next tier of states (Saudi Arabia, India, France, and Russia) and more than five times that of the following tier (the UK, Germany, Japan, and South Korea). See Tian et al. (2019).
} 
manifestation of the rivalry has been especially evident in the highly charged debate about China's ambitious Belt and Road Initiative rolled out after 2013.

An anarchic system in which the clout of two states distinguishes them from the rest provides especially strong incentives for both to remain acutely attentive to their relative capabilities and to closely monitor each other's international behavior, because each clearly recognizes the other as its most significant potential adversary. However, the constraints of international structure only partly explain the emergence of the newly broadening and sharpening US-China rivalry. It also matters that the two rivals facing these international constraints happen to be the US and China.

\section{Geography: new and more worrisome implications}

As anarchy and intimations of bipolarity encouraged China and the US to worry about their mutual vulnerabilities and to focus their attention on one another, that focus increasingly turned to the geographic space where these two countries' interests intersect, the waters of the western Pacific Ocean. Both see vital interests at stake there that make it the main theater of their rivalry, much as the main theater for US-Soviet rivalry was the middle of the European continent. These different geographic settings, however, suggest important differences between the Cold War confrontation along the central front in Europe and the one playing out in maritime Asia, differences that raise distinctive concerns.

First, the Pacific theater is not clearly divided according to each side's readily grasped vital interests, those that are too risky for the other side to challenge, because it knows it will likely provoke a reaction that creates the danger of catastrophic war. In Cold War Europe, the vital interests of the United States and the Soviet Union were quickly established by the location of their occupying armies at the end of World War II. This clearly demarcated a central front that separated blocs of allied regimes. Subsequent events (three crises over the status of Berlin and uprisings in Hungary and Czechoslovakia to which a sympathetic US dared offer only moral rather than substantive support) cemented a shared understanding about the dangers of attempting to challenge the status quo in Europe. By contrast, in the Western Pacific, the exact geographic extent of American and Chinese vital interests remains unclear, and the two countries have not yet gone through the sorts of dangerous and sobering experiences that clarified that division in Cold War Europe.

Remarkably, even in the case of the Taiwan Strait, where both sides have explicitly declared their interests, and which would seem to be the functional equivalent of the inter-German central front, analysts in China and the US still disagree about how each would react if there was a crisis triggered by a renewed challenge to the status quo. Such uncertainty increases the risk that either or both could miscalculate the reaction from the other. The precise extent of Chinese and American vital interests is even less clearly established elsewhere in the Western Pacific, where the two are still staking out positions and probing the firmness of one another's claims about their interests in the waters and airspace over the East China Sea and especially the South China Sea. Put simply, unlike the main theater of Cold War Europe, in the 
Western Pacific, it is harder to be sure about each side's "red lines" that define the vital interests over which it would risk war.

Second, the fact that the arena across which the US and China face each other is a maritime domain introduces some distinctive dangers. Unlike the fixed military positions of rivals based on land (as in Cold War Europe), even when military forces at sea (as in the Western Pacific) are not directly challenging one another, they patrol, maneuver, and exercise in areas where units from both sides are present. Ongoing surveillance, tracking, trailing, warnings, and other naval actions institutionalize a posture that nurtures an adversarial psychology. And operational intermingling increases the risk of incidents that can become crises with the potential to escalate to a larger military conflict. Indeed, incidents of this sort between the US Navy and China's People's Liberation Army Navy (and its other maritime forces) have already occurred. More troubling still, they continue to occur despite bilateral attempts to formalize "rules of the road" designed to prevent their recurrence (Glaser and Benson 2020).

\section{Nuclear weapons: old story, old implications}

Another influence shaping the rivalry between the US and China in the context of a bipolar anarchic realm is the fact that both countries are nuclear weapons states. Based on lessons from the US-Soviet Cold War experience, the implications of nuclear capabilities for today's rivalry are at once reassuring and worrisome-reassuring because of the strategic logic of nuclear deterrence and worrisome because nuclear postures reflect more than strategic logic.

Strategic logic and the Soviet-American experience through more than 4 decades of the Cold War, as well as the experiences of smaller nuclear weapons states, indicate that the possession of deliverable nuclear weapons induces caution that becomes ever greater at moments when the danger of war nears. The fear that war could quickly lead to catastrophic consequences trumps the temptation to act on plans that claim to outline a path to meaningful victory. Even on the rare occasions when nuclear-armed states have faced off in crises and limited skirmishes, they have done so cautiously and with a clear focus on preventing escalation to a general war in which the decision to use these weapons of mass destruction might not be in their own hands, but up to the adversary (Goldstein 2020). Possessing nuclear weapons that neither side can eliminate with certainty in a disarming strike, and whose catastrophic damage neither can neutralize through known defenses, greatly reduces the chances of a war between the US and China, no matter how intense their rivalry becomes.

Unfortunately, even though deterrence logically requires only having enough to threaten unacceptable retaliation, nuclear weapons states sometimes focus on relative capabilities rather than just the absolute ability to inflict punishment. The Cold War experience of the US and the Soviet Union provides plenty of evidence that concerns about the balance of nuclear capabilities can drive states to compete in building ever-larger arsenals, giving rise to an arms race. Why would states engage in a strategically pointless but economically costly nuclear buildup? The short 
answer is that the simple strategic logic of deterrence is only one influence on the decisions about the nuclear forces states deploy. The history of the Cold War suggests three reasons to worry about the potential for a US-China nuclear arms race in the new era.

First, in a bipolar world, the two leading powers' close focus on the capabilities and intentions of their most important prospective military adversary induces exaggerated fears (or hopes) that a relative advantage might matter, and motivates them to hedge against the possibility that events in a real-world confrontation might not conform with the expectations of strategic theorists. In addition, the massive resources that superpowers can muster gives them the luxury of acting on these concerns and hedging against unlikely but conceivable scenarios. During the Cold War, speculation about remote possibilities and byzantine war-fighting scenarios in which nuclear weapons would be used for purposes other than simply threatening retaliatory punishment accounted for much of the massive buildup in US and Soviet Cold War arsenals beyond the forces required for a strategy of deterrence.

Second, when a single rival becomes the key benchmark for one's international standing, invidious comparisons are readily drawn, shaping policy debates that drive strategically dubious arms buildups. During the Cold War, a focus on the relative size and sophistication of the two superpowers' nuclear arsenals fueled concerns about the ways a perceived advantage in the balance of nuclear power might somehow affect their larger competition for influence around the globe-a belief reflected in Mao Zedong's claim in 1957 about the "east wind prevailing over the west wind" after the Soviet Union was the first to demonstrate the feasibility of using intercontinental ballistic missiles to deliver nuclear warheads, as well as in the Nixon administration's doctrine of "nuclear sufficiency", which included a focus on the political significance of relative nuclear capabilities (Burr 2005).

Third, having a sole rival as the key measuring stick makes it easier for participants in domestic political debates about the adequacy of a country's military capabilities to harness concerns about invidious comparisons of nuclear warheads and delivery vehicles to their narrow purposes. Armed services, weapons manufacturers, and politicians each have incentives to play up fears about the grave risks the adversary's nuclear advantage might pose. Doing so enables them to raise a patriotic interest in national defense as the main reason that the government needs to spend more on nuclear weapon systems that benefit their organization, business, or constituents.

Bipolarity encouraged a wasteful nuclear weapon buildup during the Cold War. That experience has not yet been replicated in the new era of US-China rivalry. Unfortunately, there are reasons to think that this welcome difference may not endure much longer. First, for more than 2 decades after the collapse of the Soviet Union, the United States continued to focus on the potential dangers posed by the superpower-sized nuclear inheritance that a declining Russia maintained, rather than on those posed by China's much smaller arsenal. However, Washington has recently begun paying greater attention to the nuclear modernization of a rising Chinese superpower. When the Trump administration announced that it was withdrawing from the 1987 Intermediate-Range Nuclear Forces Treaty, it justified this step not only by referring to Russia's alleged treaty violations, but also by emphasizing that 
the bilateral treaty did not impose any limits on China while preventing the US from responding in kind to the threat which it saw in a large and growing People's Liberation Army intermediate-range arsenal in Asia. Second, as the Trump administration pondered an extension of the New START (Strategic Arms Reduction Treaty) slated to expire in February 2021, it argued that the time had come to include China in the strategic arms control regime. Although Beijing rejected the suggestion, Washington's stance is another indication that China's capabilities are now becoming part of the American calculation determining the adequacy of its own nuclear arsenal.

Second, another important reason for the hitherto muted nuclear arms competition despite increasing US-China rivalry has been Beijing's doctrinal embrace of a relatively simple deterrent strategy that requires fielding only a modest arsenal to carry out retaliatory strikes. This doctrine is arguably a sensible response to the enduring strategic significance of the nuclear revolution. However, China's limited nuclear deployments have also reflected the resource constraints it has faced. For the first 4 decades of China's nuclear development, under the leadership of Mao Zedong and then Deng Xiaoping, military modernization was subordinated to other domestic political and economic priorities. More recently, China has made comprehensive military modernization a higher priority. In this effort, however, Beijing has attached greatest urgency to funding an ambitious and expensive program of upgrading its conventional forces (especially naval forces) for contingencies in which nuclear weapons may not come into play. However, if economic growth and technological progress make available ever greater resources for investment in a wider array of military capabilities, will China's nuclear restraint endure? Will it endure as rivalry with the United States deepens, providing institutional interests in China that may favor a larger arsenal with ammunition to make their case? The Cold War experience suggests China will likely join the US in a competition that wastefully diverts national wealth to deploy nuclear weapons systems that exceed the reasonable requirements of deterrence.

\section{Cyber: new and worrisome implications}

A final key influence shaping the emerging rivalry between the US and China reflects the fact that these are two of the world's leaders in distinctively new cybertechnologies with uncertain but potentially worrisome military implications. Some of the strategic concerns raised by electronic, computer, and communications technologies often lumped together in discussions of the cyber domain began to receive attention in the last decade of the Cold War. ${ }^{8}$ However, their practical significance has blossomed in subsequent decades.

Two major concerns loom. First, military effectiveness is now dependent on networks that combine technologies that are usually more vulnerable than the weapons whose use they command and control. As a result, during a crisis or the early stages of a military confrontation, both the US and China will face incentives to ramp up

\footnotetext{
${ }^{8}$ On the early concerns, see Blair (1985) and Cohen (1996).
} 
their readiness for taking the initiative before the other side can disrupt its ability to coordinate military action and assess threats. In the lingo of strategic analysis, the importance of these sophisticated technologies for military operations increases the pressure to act preemptively, rather than to exercise the patience and restraint that facilitate crisis management and de-escalation. This new source of instability is exacerbated by the possibility that cyberattacks during great power conflict will introduce new risks of "cross-domain" escalation and undermine confidence in the robustness of nuclear deterrence. Cyberattacks could easily pose a threat to the space assets and other elements of command and control systems that, together with the weapons and delivery systems, are essential for a reliable nuclear deterrent.

Second, considerations of cyberwarfare seem likely to increase the incentives for a US-China arms race in deploying more traditional weapons. To cope with the risks of cyberwarfare, both states face incentives to build redundant military capabilities that hedge against the risk of catastrophic failures in vulnerable networks and prepare for the possible need to "fight blind". Moreover, because the effectiveness of cyberweapons is largely unproven in great power conflict, both countries have incentives to build ever-larger traditional military arsenals for the blunt use of kinetic force. Technologically less sophisticated, or at least less novel, weapons provide a proven option to neutralize the sources of cyberattacks - as long as the kinetic force is used preemptively.

\section{Conclusion}

Three of the aforementioned causes that shaped Soviet-American rivalry during the Cold War-the interaction of nuclear-armed states in the context of an anarchic international system that is bipolar-are now shaping the new era of sharpening US-China competition. These causes suggest reasons to expect the recently dramatic downturn in US-China relations to continue. However, they do not presage a future in which large-scale military conflict is likely. On the contrary, they suggest that the United States and China are probably not "destined for war", to answer the question in the title of Graham Allison's book, which popularized labeling the insights of power transition theory as the "Thucydides Trap" (Allison 2017). The Cold War experience suggests the good news that nuclear-armed superpowers locked in rivalry recognize the dire consequences of daring to move from even deep hostility to warfare. The clear and inescapable fear of prompt, obviously catastrophic outcomes, provides powerful incentives for contemporary superpowers to recognize that their interests are best served by learning to live as adversaries despite their antagonism. ${ }^{9}$

The reassuring implications of the nuclear revolution, however, do not obviate concerns that reflect two other features discussed above that distinguish the current era from its Cold War predecessor-the maritime geography of the main theater where US-China competition is focused and the unsettling and still indeterminate

\footnotetext{
9 As John Lewis Gaddis indicated, the Cold War might more aptly have been named the Long Peace, since it was noteworthy for the absence of great power war (1986). See also Yan (2019a, 40).
} 
effects of cutting edge cybertechnologies that are inextricably intertwined with the awesome military arsenals of today's superpowers. And more broadly, this analysis does not offer much reason for optimism about a reversal of the recent deterioration in US-China relations, let alone a return to the limited competition and robust cooperation that defined the previous era of engagement. Instead, the future of US-China relations seems set to resemble the fraught present. The durability of the influences shaping the current US-China relationship that I have highlighted (along with domestic political considerations that I have not addressed $)^{10}$ suggests that this fraught era of rivalry will be protracted. Because the consequences of major war in the nuclear age are clear, the US-China rivalry will most likely remain peaceful. Yet, this era of peaceful but protracted rivalry will be pitiable. The United States, China, and others seem destined to live in a world that is less prosperous, and in which the challenges of global governance are less well managed, than it would be if not for the two superpowers' deepening rivalry.

In sum, the dawning era of US-China relations will not be a clone of the twentieth century's Cold War. It is not yet, and may never be, defined by the global ideological contestation, full economic separation, and military competition in proxy wars that characterized Soviet-American rivalry. Nevertheless, international and national influences are now shaping a twenty-first century relationship between the United States and China that, while distinctive, shares unfortunate similarities with the decades-long era of US-Soviet antagonism and introduces some new, unsettling risks.

\section{References}

Allison, Graham T. 2017. Destined for war: can America and China escape Thucydides's trap?. Boston: Houghton Mifflin Harcourt.

Allison, Graham T. 2018. The US is hunkering down for a new cold war with China. Financial Times.https://www.ft.com/content/666b0230-cd7b-11e8-8d0b-a6539b949662. Accessed 15 Mar 2020.

Blair, Bruce G. 1985. Strategic command and control: redefining the nuclear threat. Washington: Brookings Institution.

\footnotetext{
${ }^{10}$ Many of the key domestic political influences that $\mathrm{I}$ have set aside in this assessment provide additional reason to expect that the rivalry will persist. These include: electoral dynamics in the United States that encourage candidates to position themselves as tougher on China than their opponents; concerns about performance legitimacy for the Chinese Communist Party that provide incentives to stake out strong nationalist positions and stand firm in conflicts with the United States; and longstanding but newly revived disagreements about human rights issues that reflect the different politics, culture, and history of a liberal democratic United States and an authoritarian China. One other domestic influence on bilateral relations is the role played by national political leaders. Although it is rare for individuals to decisively alter trends that reflect the constraints of international structure and domestic politics, bold leaders can mitigate (or exacerbate) the intensity of the rivalry. This, too, is a lesson one can draw from the Cold War experience, in which US-Soviet relations passed through periods of tense confrontation and relative relaxation in part because of the way key leaders on each side chose to manage the rivalry. See Gaddis (1982), Byman and Pollack (2001), Yan (2019b) and Zakaria (2020).
} 
Burr, William. 2005. The Nixon Administration, the "Horror Strategy," and the search for limited nuclear options, 1969-1972: prelude to the schlesinger doctrine. Journal of Cold War Studies 7 (3): 34-78.

Byman, Daniel L., and Kenneth M. Pollack. 2001. Let us now praise great men: bringing the statesman back in. International Security 25 (4): 107-146. https://doi.org/10.1162/016228801510919 16.

Clinton, Hillary Rodham. 2011. America's pacific century. Foreign Policy 189: 56-63.

Cohen, Eliot A. 1996. A revolution in warfare. Foreign Affairs 75 (2): 37-54. https://doi. org/10.2307/20047487.

Edel, Charles, and Hal Brands. 2019. The real origins of the US-China cold war. Foreign Policy. https ://foreignpolicy.com/2019/06/02/the-real-origins-of-the-u-s-china-cold-war-big-think-commu nism/. Accessed 15 Mar 2020.

Farrell, Henry, and Abraham L. Newman. 2019. Weaponized interdependence: how global economic networks shape state coercion. International Security 44 (1): 42-79. https://doi.org/10.1162/ isec_a_00351.

Ferguson, Niall. 2019. The New Cold War? It's with China, and it has already begun. New York Times. https://www.nytimes.com/2019/12/02/opinion/china-cold-war.html. Accessed 15 Mar 2020.

Gaddis, John Lewis. 1982. Strategies of containment: a critical appraisal of Postwar American National Security Policy. New York: Oxford University Press.

Gaddis, John Lewis. 1986. The long peace: elements of stability in the postwar international system. International Security 10 (4): 99-142. https://doi.org/10.2307/2538951.

Glaser, Bonnie, and Jeff W. Benson. 2020. Conflict prevention in the South China Sea depends on China abiding by the existing rules of navigation. South China Morning Post. https://www.scmp. com/comment/opinion/article/3052429/conflict-prevention-south-china-sea-depends-china-abidi ng-existing. Accessed 19 Mar 2020.

Goldstein, Avery. 2020. The end of the beginning: China and the consolidation of the nuclear revolution. In The age of Hiroshima, ed. Michael D. Gordin, and G. John Ikenberry, 221-242. Princeton: Princeton University Press.

Kaplan, Robert D. 2019. A new cold war has begun. Foreign Policy. https://foreignpolicy. com/2019/01/07/a-new-cold-war-has-begun/. Accessed 15 Mar 2020.

Khong, Yuen Foong. 1992. Analogies at war: Korea, Munich, Dien Bien Phu, and the Vietnam decisions of 1965. Princeton: Princeton University Press.

Khong, Yuen Foong. 2019. The US, China, and the Cold War analogy. China International Strategy Review 1 (2): 223-237. https://doi.org/10.1007/s42533-020-00034-y.

Lake, David A. 2017. Domination, authority, and the forms of Chinese Power. Chinese Journal of International Politics 10 (4): 357-382. https://doi.org/10.1093/cjip/pox012.

Leffler, Melvyn P. 2019. China isn't the Soviet Union. Confusing the two is dangerous. The Atlantic. https:/www.theatlantic.com/ideas/archive/2019/12/cold-war-china-purely-optional/601969/. Accessed 15 Mar 2020.

Lind, Michael. 2018. Cold War II. National Review. https://www.nationalreview.com/magaz ine/2018/05/28/us-china-relations-cold-war-ii/. Accessed 15 Mar 2020.

Marston, Hunter. 2019. The US-China cold war is a myth. Foreign Policy. https://foreignpolicy. com/2019/09/06/the-u-s-china-cold-war-is-a-myth/. Accessed 18 Nov 2019.

May, Ernest R. 1973. "Lessons” of the past: the use and misuse of history in American foreign policy. New York: Oxford University Press.

Mead, Walter Russell. 2019. Beijing will give you Cold War nostalgia: nuclear deterrence was simple compared with the fluid nature of cyberwarfare. Wall Street Journal. https://www.wsj.com/artic les/beijing-will-give-you-cold-war-nostalgia-11572909192. Accessed 15 Mar 2020.

Mearsheimer, John J. 2001. The tragedy of great power politics. New York: Norton.

Medeiros, Evan S. 2019. The changing fundamentals of US-China relations. The Washington Quarterly 42 (3): 93-119.

The Economist. 2019. A new kind of cold war. https://www.economist.com/leaders/2019/05/16/anew-kind-of-cold-war. Accessed 15 Mar 2020.

Tian, Nan, Aude Fleurant, Alexandra Kuimova, Pieter D. Wezeman, and Siemon T. Wezeman. 2019. Trends in world military expenditure, 2018. Stockholm International Peace Research Institute. https://www.sipri.org/sites/default/files/2019-04/fs_1904_milex_2018_0.pdf. Accessed 19 Mar 2020 . 
Tunsjø, Øystein. 2018. The return of bipolarity in world politics: China, the United States, and geostructural realism. New York: Columbia University Press.

Waltz, Kenneth N. 1979. Theory of international politics. Menlo Park: Addison-Wesley Publishing Co.

Yan, Xuetong. 2015. Why a bipolar world is more likely than a unipolar or multipolar one. New Perspectives Quarterly 32 (3): 52-56. https://doi.org/10.1111/npqu.11529.

Yan, Xuetong. 2019a. The age of uneasy peace: Chinese power in a divided world. Foreign Affairs 98 (1): 40-46.

Yan, Xuetong. 2019b. Leadership and the rise of great powers. Princeton: Princeton University Press.

Zakaria, Fareed. 2020. The new China scare: why America shouldn't panic about its latest challenger. Foreign Affairs 99 (1): 52-69. 